\title{
Methionine-balanced diets improve cattle performance in fattening young bulls fed high-forage diets through changes in nitrogen metabolism
}

\author{
G. Cantalapiedra-Hijar ${ }^{1 *}$, I. Ortigues-Marty ${ }^{1}$, B. Sepchat ${ }^{2}$, E. Titgemeyer ${ }^{3}$ and L. Bahloul ${ }^{4}$ \\ ${ }^{1}$ INRAE-VetAgroSup, Unité Mixte de Recherches sur les Herbivores, 63122 St Genès Champanelle, France \\ ${ }^{2} I N R A E$, UE Herbipôle, 63122 St Genès Champanelle, France \\ ${ }^{3}$ Department of Animal Sciences and Industry, Kansas State University, Manhattan, KS 66506, USA \\ ${ }^{4}$ Centre of Expertise and Research in Nutrition, Adisseo France, O3600 Commentry, France
}

(Submitted 26 January 2020 - Final revision received 18 March 2020 - Accepted 19 March 2020 - First published online 30 March 2020)

\section{Abstract}

Ruminants fed high-forage diets usually have a low feed efficiency, and their performances might be limited by methionine (Met) supply. However, the INRA feeding system for growing cattle does not give recommendation for this amino acid (AA). This study aimed to assess the effects of Met-balanced diets on animal performance and $\mathrm{N}$ metabolism in young bulls fed high-forage diets formulated at or above protein requirements. Four diets resulting from a factorial arrangement of two protein levels (Normal ( $13.5 \%$ crude protein) $v$. High ( $16 \cdot 2 \% \mathrm{crude}$ protein)) crossed with two Met concentrations (unbalanced ( $2.0 \%$ of metabolisable protein) $v$. balanced ( $2.6 \%$ of metabolisable protein)) were tested on thirty-four fattening Charolais bulls for 7 months before slaughter. Animal growth rate was greater in Met-balanced diets $(+8 \%$; $P=0.02)$ with a trend for a greater impact in High $v$. Normal protein diets $(P=0 \cdot 10)$. This trend was observed in lower plasma concentrations of branched-chain AA only when Met supplementation was applied to the Normal protein diet $(P \leq 0 \cdot 06)$ suggesting another co-limiting AA at Normal protein level. Feed conversion efficiency and $\mathrm{N}$ use efficiency were unaffected by Met supplementation $(P>0 \cdot 05)$. However, some plasma indicators suggested a better use of AA when High protein diets were balanced $v$. unbalanced in Met. The proportion of total adipose tissue in carcass increased ( +5 percent units; $P=0 \cdot 03$ ), whereas that of muscle decreased on average $0 \cdot 8$ percent units $(P=0 \cdot 05)$ in Met-balanced diets. Our results justify the integration of AA into dietary recommendations for growing cattle.

\section{Key words: Amino acids: Rumen-protected methionine: Beef cattle: Grass silage: Protein metabolism}

Ruminant production systems should evolve towards the improvement of animal feed efficiency, the animal's ability to transform feed into food in a context of minimising the use of human-edible resources ${ }^{(1)}$. Beef cattle have a low biological feed conversion efficiency (FCE) compared with other livestock species $^{(2)}$. However, grazing cattle fed high-forage diets can be greater net protein producers compared with other livestock species, supplying more human-edible protein than they consume ${ }^{(3)}$. Thus, feeding strategies should be proposed to farmers to increase the profitability of the beef cattle sector in a context of increasing the use of diets based on cellulosic feedstuffs, which paradoxically are resources promoting low biological feed to food conversion efficiency.

Protein supplementation, and specifically rumen-undegradable protein, has been shown to improve performance in growing cattle fed high-forage diets ${ }^{(4)}$. This suggests that rumen bypass protein may correct for an amino acid (AA) deficiency. In this sense, methionine (Met) has been suggested ${ }^{(5)}$ and demonstrated ${ }^{(6)}$ to be the first-limiting AA for growth of ruminants depending only on microbial protein. Because microbial contribution to metabolisable protein is very high in forage-fed ruminants ${ }^{(7)}$, Met can be expected to be the first-limiting AA in growing cattle fed highforage diets ${ }^{(8,9)}$. Moreover, meeting AA requirements becomes more crucial during stages of high productivity. Indeed, net protein requirements are relatively high in growing young bulls of late maturing breeds (Charolais, Simmental or Limousin), retaining $35-45 \%$ of their energy as protein ${ }^{(10)}$. In this situation, cattle cannot always satisfy their AA requirements with only microbial supplies and extra rumen bypass protein needs to be supplied with the resulting higher feeding costs. Thus, post-ruminal Met supplementation may be required in rapidly growing animals fed high-forage $\operatorname{diets}^{(11)}$.

The principle of limiting AA in animal production is well established in swine and dairy cattle. Although a positive impact of AA supplementation on beef cattle performance has been reported in the literature ${ }^{(12)}$, the current French feeding system

Abbreviations: AA, amino acid; ADG, average daily gain; BW, body weight; $\mathrm{CP}$, crude protein; FCE, feed conversion efficiency; Met, methionine; NUE, nitrogen use efficiency.

* Corresponding author: G. Cantalapiedra-Hijar, email gonzalo.cantalapiedra@inrae.fr 
includes no AA recommendations for this type of animal ${ }^{(7)}$. With the evolution of animal genotypes in recent decades towards higher productivity phenotypes and the predictable enhancement of cellulose incorporation in ruminant rations, there is a need to first evaluate the impact of balancing diets for AA supply on beef cattle performances and then to study the metabolic mechanisms underlying the improvement in growth efficiency.

We hypothesised that like in dairy cows, the principle of limiting AA also applies to growing cattle and so supplementing rumen-protected Met to high-forage diets containing low metabolisable Met content would improve the performance of fastgrowing beef cattle through a better $\mathrm{N}$ use efficiency (NUE). We also expected that this improvement would be greater as dietary protein level decreases. Therefore, the objective of this study was to assess the effects of Met-balanced diets on animal performance, feed efficiency and $\mathrm{N}$ metabolism in growingfattening Charolais bulls fed high-forage diets formulated to supply protein close to or above requirements. Estimations of body composition together with the analysis of plasma metabolites and the assessment of the isotopic turnover rate of plasma proteins were used to interpret changes in $\mathrm{N}$ metabolism.

\section{Materials and methods}

The experiment was conducted at Herbipôle (INRA, UE 1414) in compliance with the National Legislation on Animal Care. The C2EA-02 animal research ethics committee (Auvergne, France) prospectively approved this research, and thereafter the Ministry of Agriculture (France) validated it with the approval number 7180-2016101016361277v4. Animals were continuously monitored by trained staff for signs of pain, suffering and distress associated with the procedures further described as well as routinely assessed for health and welfare problems.

\section{Animal, diets and measurements}

Thirty-six growing-fattening Charolais bulls (320 (SD 33) kg and 266 (SD 22) d) were evenly assigned, according to their age, weight and pre-weaning performance, to one of the four experimental diets ( $n$ 9/treatment). Experimental diets (Table 1) resulted from a factorial $2 \times 2$ design: two dietary metabolisable protein levels (100\% (Normal) v. $120 \%$ (High) of requirements $\left.{ }^{(7)}\right)$ and two dietary Met concentrations (unbalanced $v$. balanced $(+\mathrm{M})$ diets). Diets were formulated for similar net energy content and consisted of $54 \%$ grass silage, $6 \%$ wheat straw and $40 \%$ concentrate (DM basis) with amounts adjusted daily to ensure at least $10 \%$ refusals. Experimental diets were formulated to supply 1.4 times the net energy maintenance requirements and to promote about $1.40 \mathrm{~kg} / \mathrm{d}$ of average daily gain (ADG) according to the INRA feeding system for young Charolais bulls of about $500 \mathrm{~kg}$ of body weight $(\mathrm{BW})^{(7)}$. Greater protein content in High $v$. Normal protein diets was mostly achieved by replacing some wheat by a commercial formaldehyde-treated soyabean meal (48\% crude protein (CP) soyabean meal with $1 \%(\mathrm{w} / \mathrm{w})$ of a solution made from $30 \%$ of formalin $+5 \%$ of methanol, NatUp), which increased protein in the diet mostly through the supply of rumen bypass protein (more than $70 \%$ of $\mathrm{CP}$ according to INRA tables $\left.{ }^{(7)}\right)$. The addition of rumen-protected Met (Smartamine $\mathrm{M}^{\circledR}$, Adisseo France) was identical across the two dietary protein levels $(7 \mathrm{~g} / \mathrm{d}$ throughout the study). Smartamine M was top-dressed over the total mixed ration. Smartamine $\mathrm{M}$ is composed of small beads, containing a minimum of $75 \%$ DL-Met, protected physically by a $\mathrm{pH}-$ sensitive coating, having a Met bioavailability of $80 \%{ }^{(13)}$. Therefore, it was assumed that $7 \mathrm{~g}$ of Smartamine M provided animals with $4.2 \mathrm{~g}$ of metabolisable Met. Because no specific recommendations are currently provided by the INRA feeding system $^{(7)}$ for growing cattle, this amount of Met supplementation was designed to slightly exceed the metabolisable Met requirement for dairy cattle $\left(2 \cdot 4 \%\right.$ of metabolisable protein $\left.{ }^{(7)}\right)$. The estimated Met content was $2.6 \%$ of metabolisable protein on average in balanced diets and almost $25 \%$ lower (about $2.0 \%$ of metabolisable protein) for the unbalanced diets.

Animals were housed in free stalls equipped with electronic gates (Dairy gate ${ }^{\circledR}$ ) to measure individual daily feed intake. Diets were distributed as total mixed ration (TMR) once daily (08.00 hours), and water was freely available. The experiment was preceded by a 5-week transition period to allow the animals to adapt to diets. Daily amounts of TMR as well as individual refusals were precisely weighed to calculate individual feed intakes throughout the performance test. DM was measured twice a week for feed ingredients and daily for TMR and refusals $\left(103^{\circ} \mathrm{C}, 48 \mathrm{~h}\right)$. Feed samples pooled over the whole experiment were stored at $-20^{\circ} \mathrm{C}$ before analysis. At the start of the experiment, animals were weighed on two consecutive days, fortnightly thereafter, and finally on two consecutive days just before slaughter. Bulls were always weighed at 13.30 hours without a previous feed restriction. Ultrasound echography measurements were performed over time for evaluating the composition of BW gain. Ultrasound echography (Aloka Prosound 2 with a linear probe UST5820-5) was conducted every month from the start to the end of the performance test $(n 7)$ and in three different anatomical places per animal and time (latissimus dorsi muscle between the 12th and 13th rib, gluteus superficialis muscle between the Tuber coxae and Tuber ischiadicum, and gluteus medius muscle at the 4th lumbar vertebrae level between the transverse process) after trimming the hair coat with a handheld electric clipper. Distances analysed from each anatomical place were the skin (D0) and backfat thickness (D1) that include both subcutaneous tissues and skin. The thickness of subcutaneous adipose tissue and connective tissues was calculated as D1-D0.

Animals were slaughtered at the INRA experimental slaughterhouse of UE1414 Herbipôle Unit at a rate of four animals per week once the first dietary treatment reached on average of $720 \mathrm{~kg} \mathrm{BW}$ (corresponding to a target market carcass weight of about $420 \mathrm{~kg}$ ). All four animals were slaughtered on the same day within each week. Slaughter was carried out during 2 months (May and June 2017), and every day one animal from each dietary treatment was slaughtered to keep on average the same experimental duration (from start to the slaughter) across dietary treatments.

Hot carcass, internal fat (i.e. heart, mesenteric, pelvic and kidney fat) and visceral organ weights were recorded. Carcasses were graded for conformation and fat score according to the 
Table 1. Ingredients, chemical composition and nutritive values of experimental diets tested on fattening Charolais bulls

\begin{tabular}{|c|c|c|c|c|}
\hline & \multicolumn{4}{|c|}{ Diets } \\
\hline & Normal & Normal $+\mathrm{M}$ & High & $\mathrm{High}+\mathrm{M}$ \\
\hline \multicolumn{5}{|l|}{ Ingredient composition (\% of DM) } \\
\hline Grass silage & $53 \cdot 0$ & $53 \cdot 0$ & $53 \cdot 0$ & $53 \cdot 0$ \\
\hline Wheat grain & $23 \cdot 2$ & $23 \cdot 2$ & $16 \cdot 0$ & $16 \cdot 0$ \\
\hline Beet pulp & $14 \cdot 8$ & $14 \cdot 8$ & $14 \cdot 8$ & $14 \cdot 8$ \\
\hline Formaldehyde-treated soyabean meal & $2 \cdot 0$ & $2 \cdot 0$ & $9 \cdot 2$ & $9 \cdot 2$ \\
\hline Wheat straw & $6 \cdot 2$ & $6 \cdot 2$ & $6 \cdot 2$ & $6 \cdot 2$ \\
\hline Bicarbonate & 0.6 & 0.6 & 0.6 & 0.6 \\
\hline Minerals and vitamin $\mathrm{mix}^{*}$ & 0.2 & 0.2 & 0.2 & 0.2 \\
\hline \multicolumn{5}{|l|}{ Chemical composition (\% of DM) } \\
\hline $\mathrm{OM}$ & $91 \cdot 1$ & $91 \cdot 1$ & $90 \cdot 9$ & $90 \cdot 9$ \\
\hline $\mathrm{CP}$ & 13.5 & 13.5 & $16 \cdot 2$ & $16 \cdot 2$ \\
\hline NDF & $42 \cdot 0$ & $42 \cdot 0$ & $42 \cdot 4$ & $42 \cdot 4$ \\
\hline ADF & $24 \cdot 2$ & $24 \cdot 2$ & 24.4 & 24.4 \\
\hline Starch & $16 \cdot 8$ & $16 \cdot 8$ & $12 \cdot 9$ & $12 \cdot 9$ \\
\hline \multicolumn{5}{|l|}{ In vitro enzymatic digestibility (\%) } \\
\hline $\mathrm{OM}+$ & 74.4 & 74.4 & 74.4 & 74.4 \\
\hline $\mathrm{CP} \ddagger$ & 73.9 & 73.9 & $66 \cdot 7$ & $66 \cdot 7$ \\
\hline \multicolumn{5}{|l|}{ Feed values§ } \\
\hline NE (Mcal/kg) & 1.50 & 1.50 & 1.53 & 1.53 \\
\hline PDIA (g/kg) & 20 & 20 & 37 & 37 \\
\hline PDI $(\mathrm{g} / \mathrm{kg})$ & 73 & 73 & 89 & 89 \\
\hline $\mathrm{PDI} / \mathrm{NE} \|$ (g/Mcal) & 49 & 49 & 58 & 58 \\
\hline MetDIn (\% of PDI) & $2 \cdot 1$ & $2 \cdot 8$ & $2 \cdot 0$ & 2.5 \\
\hline Microbial contribution (\%) & $86 \cdot 1$ & 64.8 & $75 \cdot 0$ & $58 \cdot 3$ \\
\hline PDIA contribution (\%) & 13.9 & $10 \cdot 4$ & $25 \cdot 0$ & 19.5 \\
\hline RPM contribution (\%) & - & 24.8 & - & $22 \cdot 2$ \\
\hline LysDIף ( $\%$ of PDI) & $7 \cdot 0$ & 7.0 & 6.9 & 6.9 \\
\hline LysDI/MetDI & 3.4 & 2.5 & 3.5 & $2 \cdot 7$ \\
\hline
\end{tabular}

$\mathrm{OM}$, organic matter; $\mathrm{CP}$, crude protein; NDF, neutral-detergent fibre; ADF, acid-detergent fibre; NE, net energy; PDIA, rumen-bypass protein digestible in the intestine; PDI, protein digestible in the small intestine (metabolisable protein); RPM, rumen-protected methionine.

* Minerals and vitamin mix: $5 \% \mathrm{P}, 25 \% \mathrm{Ca}, 8 \% \mathrm{Mg}, 0.2 \% \mathrm{Na}$, vitamin A (210 mg $/ \mathrm{kg})$, vitamin $\mathrm{D}_{3}(3.75 \mathrm{mg} / \mathrm{kg})$, vitamin E $(2730 \mathrm{mg} / \mathrm{kg})$ and vitamin $B_{1}(4.5 \mathrm{mg} / \mathrm{kg})$.

† Estimated from enzymatic digestion with pepsin-cellulase ${ }^{(21)}$

‡ Estimated from an enzymatic hydrolysis assay ${ }^{(20)}$ for concentrates or from chemical composition for grass silage.

$\S$ Feed values were estimated from analysed chemical composition and INRA2018 equations using Systoolweb version 1.2 (www.systool.fr).

| PDI:NE ratio. Recommended values are between 53 and 48 for body weights of 300 and $600 \mathrm{~kg}$, respectively, in fattening Charolais bulls ${ }^{(7)}$

II Percentage of Met and Lys in metabolisable protein estimated using INRA (2018) equations ${ }^{(7)}$, analysed amino acid profile in feed samples and observed DM intake during the experimental period. Recommended values for LysDI and MetDI are, respectively, 7.0 and $2.4 \%$ of PDI for dairy $\operatorname{cows}^{(7)}$.

EU classification on a fifteen-point scale and chilled and stored at $4^{\circ} \mathrm{C}$ until $24 \mathrm{~h}$ post-mortem.

\section{Isotopic nitrogen turnover rate}

Following a change in the dietary isotopic composition, animal's tissues progressively assimilate the new dietary isotopic signature ${ }^{(14-16)}$. The rate at which this occurs is known as the isotopic turnover rate and depends largely on how fast the metabolic tissue replacement occurs ${ }^{(17)}$. We applied this lessinvasive method to indirectly evaluate changes in the fractional protein synthesis rate of animal proteins resulting from our experimental conditions. For this, all animals were progressively enriched in ${ }^{15} \mathrm{~N}$ over $35 \mathrm{~d}$ while adapting to their respective diet (from day -36 to day -1 ); each animal received daily in the morning (08.30 hours) a capsule $(10 \times 3 \mathrm{~mm})$ containing $20 \mathrm{mg}$ of ${ }^{15} \mathrm{~N}$-labelled urea $(98 \%$ atom percent excess; SigmaAldrich). The capsule was mixed with about $200 \mathrm{~g}$ of concentrate (the one assigned to the animal) in a small bucket within the feeder just before the only meal distribution (09.00 hours). At 20 min after administration, it was systematically checked that the capsule had been swallowed by the animal. The rest of the diet was then distributed to the feeder. On day 0 (onset of the experiment), animals no longer received the ${ }^{15} \mathrm{~N}$-labelled urea and blood was sampled from that day onwards as further detailed. Kinetic equations of ${ }^{15} \mathrm{~N}$ depletion in plasma proteins from these same animals have been previously published in a methodological paper ${ }^{(17)}$.

\section{In vivo sampling}

At the onset of the experiment (day 0), all animals were biopsied under local anaesthesia from the middle of a triangle formed by the last lumbar vertebrae, tail base and ischial tuberosity. Subcutaneous adipose tissue was sampled to determine the diameter of adipocytes and thus to estimate the fat mass in the empty BW at the beginning of the trial according to INRA equations previously detailed ${ }^{(18)}$.

To determine the $\mathrm{N}$ isotopic turnover rate in plasma proteins, blood was sampled at 08.00 hours (during meal distribution) by venepuncture from the caudal vein of all animals on days $0,3,7$, $11,15,21,35,49,77$ and 142 ( $n 10$ per animal) after stopping the ${ }^{15} \mathrm{~N}$-labelled urea administration. Blood was collected into 9-ml evacuated tubes (BD vacutainer) containing lithium heparin as 
an anticoagulant, centrifuged within the first hour at $2500 \mathbf{g}$ for $15 \mathrm{~min}$ at $4^{\circ} \mathrm{C}$ and stored at $-20^{\circ} \mathrm{C}$ for determination of $\delta^{15} \mathrm{~N}$ values in total plasma proteins as previously described ${ }^{(18)}$.

Plasma samples obtained on days 21, 77 and 142 after stopping the ${ }^{15} \mathrm{~N}$-urea administration (start, middle and end of the fattening period) were also used for analysing acetate, $\beta$ hydroxy-butyrate, glucose and urea, while only those obtained on days 77 and 142 were analysed for AA and AA-related metabolites through a targeted metabolomics approach.

\section{Laboratory analyses}

Feeds were ashed at $550^{\circ} \mathrm{C}$ for $6 \mathrm{~h}$ for organic matter (OM) determination. $\mathrm{N}$ content was analysed by the Dumas method (norm ISO205 16634-1, 2008, using a Rapid N Cube, Elementar Analysensysteme $\mathrm{GmbH}$ ). Neutral-detergent fibre and aciddetergent fibre were determined according to Van Soest et $a l^{(19)}$. The enzymatic CP degradability of concentrates was determined by in vitro protease hydrolysis for $1 \mathrm{~h}$ according to Aufrère \& Cartailler ${ }^{(20)}$, whereas the enzymatic OM digestibility was assessed as described by Aufrère ${ }^{(21)}$. The AA composition of feed (grass silage and concentrate) was analysed using an HPLC (Alliance System, Waters) following protein hydrolysis with $6 \mathrm{~m} \mathrm{HCl}(24 \mathrm{~h})$. The sulfur AA (i.e. Met and Cys) were analysed separately by oxidation using performic acid before the protein hydrolysis. For analysis of tryptophan, alpha methyl DL-Trp was added to the sample, followed by hydrolysis in barium hydroxide in the absence of $\mathrm{O}_{2}$ using an autoclave. After the acidification of an aliquot fraction, tryptophan was separated by HPLC using a fluorimetric detector.

Plasma concentrations of glucose, $\beta$-hydroxybutyric acid, NEFA and urea were analysed by spectrophotometry with an automated analyzer (Arene 20XT, Thermo Scientific). For the targeted metabolomics approach, electrospray ionisation MS was performed on plasma samples using the Absolute IDQ p 180 (Biocrates Life Science AG). Only AA and related compounds are presented here.

\section{Nitrogen stable isotope analysis}

The $\mathrm{N}$ isotopic composition $\left(\delta^{15} \mathrm{~N}\right)$ of freeze-dried plasma proteins and ground-dried diet ingredients was determined using an isotope-ratio mass spectrometer (Isoprime; VG Instruments) coupled to an elemental analyser (EA Isoprime; VG Instruments). Internal standards (glutamic acid) were included in every run to correct for possible variations in the raw values determined by the mass spectrometer. Results were expressed using the delta notation according to the following equation:

$$
\delta^{15} \mathrm{~N}=\left(\left(\mathrm{R}_{\text {sample }} / \mathrm{R}_{\text {standard }}\right)-1\right) \times 1000
$$

where $R_{\text {sample }}$ and $R_{\text {standard }}$ are the $\mathrm{N}$ isotope ratio between the heavier isotope and the lighter isotope $\left({ }^{15} \mathrm{~N}:{ }^{14} \mathrm{~N}\right)$ for the sample being analysed and the internationally defined standard (atmospheric $\mathrm{N}_{2}, \mathrm{R}_{\text {standard }}=0.0036765$ ), respectively, and $\delta$ is the delta notation in parts per 1000 (\%) relative to the standard.

\section{Isotopic turnover rate modelling}

The post-diet switch $\delta^{15} \mathrm{~N}$ kinetics measured in plasma protein were analysed according to a mono-exponential model ${ }^{(22)}$ :

$$
\delta^{15} \mathrm{~N}(\mathrm{t})=\delta^{15} \mathrm{~N}_{\infty}+\left(\delta^{15} \mathrm{~N}_{0}-\delta^{15} \mathrm{~N}_{\infty}\right) \times \exp ^{-\mathrm{kt}}
$$

where $t(d)$ is the time since the ${ }^{15} \mathrm{~N}$ diet-switch, $\delta^{15} \mathrm{~N}(\mathrm{t})(\% \mathrm{o})$ is the $\delta^{15} \mathrm{~N}$ value in plasma proteins at time $\mathrm{t}, \delta^{15} \mathrm{~N}_{0}(\%)$ is the initial $\delta^{15} \mathrm{~N}$ value and $\delta^{15} \mathrm{~N}_{\infty}(\%)$ is the asymptotic value of plasma proteins after the animal has reached isotopic steady state with its basal diet (without ${ }^{15} \mathrm{~N}$-urea administration). The parameter $\mathrm{k}\left(\mathrm{d}^{-1}\right)$ is the fractional $\mathrm{N}$ isotopic turnover rate in plasma proteins. The model parameters (i.e. $\delta^{15} \mathrm{~N}_{\infty}, \delta^{15} \mathrm{~N}_{0}$ and k) were estimated using a non-linear procedure and statistically analysed through a non-linear mixed-effect model (nlme package $\left.{ }^{(23)}\right)$ fitted by maximum likelihood in the R software ${ }^{(24)}$ with experimental dietary factors (protein content, Met content and their interaction) considered as fixed effects and the animal as a random effect. Significant effects were declared when $P \leq 0 \cdot 05$, and a trend was considered when $0.05<P<0 \cdot 10$.

\section{Calculations and statistical analysis}

Dietary feed values (Table 1) were calculated using INRA equations $^{(7)}$ and the systoolweb software (www.systool.fr) from analysed chemical composition, in vitro digestibility measurements (Upscience-Labs, Saint-Nolf, France), and observed DM intakes and average animal BW.

Body composition (protein and lipid contents) at the onset and end of the experiment was estimated as previously reported $^{(18)}$. Briefly, starting body composition was estimated from the diameter of subcutaneous adipose cells and equations proposed by Garcia \& Agrabriel ${ }^{(25)}$, whereas carcass tissue composition (bone, muscle and fat) at the end of the experiment (slaughterhouse) was estimated using the equations proposed for Charolais bulls ${ }^{(26)}$. Further estimations of chemical wholebody composition (ash, protein and lipids) were performed from estimated carcass tissue composition and measured internal fat weights ${ }^{(27)}$. Whole-body protein and lipid gains during the experiment were calculated by differences between final and starting body compositions.

ADG was calculated as:

$$
\operatorname{ADG}(\mathrm{kg} / \mathrm{d})=\left(\mathrm{BW}_{\text {slaugther }}-\mathrm{BW}_{\text {onset }}\right) / \text { Time }(\mathrm{d})
$$

Where $\mathrm{BW}_{\text {slaughter }}$ and $\mathrm{BW}_{\text {onset }}$ are the mean body weights recorded on two consecutive days just before the slaughter and the onset of the experiment, respectively, with Time being the number of days between the two measurements.

FCE was calculated as:

$$
\text { FCE }(\mathrm{kg} / \mathrm{kg})=\operatorname{ADG}(\mathrm{kg} / \mathrm{d}) / \mathrm{DM} \text { intake }(\mathrm{kg} / \mathrm{d})
$$

With ADG and DM intake both individually measured between the onset of the experiment (day 0) and slaughter. 
NUE was calculated as:

$$
\text { NUE }(\mathrm{kg} / \mathrm{kg})=\text { body } \mathrm{N} \text { retention }(\mathrm{kg}) / \mathrm{N} \text { intake }(\mathrm{kg})
$$

Where body $\mathrm{N}$ retention and $\mathrm{N}$ intake represent the amount of $\mathrm{N}$ retained and ingested, respectively, between the onset of the experiment and the slaughter. Body $\mathrm{N}$ retention was calculated from the estimated body protein retention divided by $6 \cdot 25$.

The $\Delta^{15} \mathrm{~N}$ or isotopic discrimination factor between the animal and the diet was calculated as $\delta^{15} \mathrm{~N}$ of plasma proteins on day 142 (time point at equilibrium) minus $\delta^{15} \mathrm{~N}$ of the diet, the latter was calculated as the average of $\delta^{15} \mathrm{~N}$ of each ingredient weighted by the percentage of $\mathrm{N}$ the ingredient represents in the diet.

Power analysis conducted according to Kadam \& Bhalerao ${ }^{(28)}$ indicated that a minimum of eight animals per treatment were necessary to detect a statistical difference $(\alpha=0 \cdot 05 ; \beta=0 \cdot 80)$ equal to the effect size of Met content on ADG previously reported with similar diets $\left(+14 \%^{(29)}\right)$ and given the average and standard deviation values of ADG observed in similar conditions $\left(1.65(\mathrm{sD} 0 \cdot 16) \mathrm{kg} / \mathrm{d}\right.$, respectively $\left.{ }^{(30)}\right)$. Therefore, nine animals per treatment were chosen for this study.

Animal was considered the experimental unit. Repeated measures (ultrasound data and plasma metabolites) were analysed by mixed effects models using the nlme package in $\mathrm{R}$ software (version 3.0.1.) with animal as a random effect and time, dietary protein content, dietary Met content and their interaction as fixed effects. Non-repeated measures were analysed by ANOVA in R using the $\mathrm{lm}$ function with dietary protein content, dietary Met content and their interaction as fixed effects. Significant results were declared when $P<0.05$, whereas trends were accepted at $P<0 \cdot 10$. Mean values are reported as least square means with pooled SEM values due to missing observations. When the interaction between main effects was significant, the dietary treatment means were compared using Tukey's honest significant difference multiple comparison. The significance of treatment effect was set at $P<0.05$.

\section{Results}

From the thirty-six animals starting the experiment, two animals (one fed Normal protein-unbalanced diet and the other fed Normal protein-balanced diet) did not finish the experiment due to health problems unrelated to the experimental treatments.

\section{In vivo performance}

As shown in Table 2, average daily gain was improved when dietary protein content increased $(+8 \% ; P=0.03)$ or when diets were balanced for Met $(+8 \% ; P=0 \cdot 02)$, with a trend for a greater effect of Met in High $v$. Normal protein diets $(\mathrm{P} \times \mathrm{M} ; P=0 \cdot 10)$. Although DM intake remained similar across diets $(P>0 \cdot 10)$, $\mathrm{N}$ intake was, as expected, higher $(+21 \% ; P<0.001)$ with High compared with Normal protein diets. High protein diets tended to promote better FCE compared with Normal protein diets $(+6 \% ; P=0.06)$, but this was associated with a worse NUE $(-13 \% ; P=0.001)$. Despite a numerical improvement in FCE and NUE when High protein diets were balanced as compared with unbalanced in Met $(+8.5$ and $+5.1 \%$, respectively), no significant effect of Met-balancing diet on these variables was observed $(P=0.11$ and 0.45 , respectively). Average fat depth measured at four different anatomical levels by ultrasound was similar across dietary treatments at the start of the experiment $(P=0 \cdot 22)$, but was greater for High $v$. Normal protein diets at the end of the test $(P=0 \cdot 001)$. The average gain in fat depth across time, measured as the slope of fat depth on time $(n 7)$, was increased by Met balancing only with High protein diets $(\mathrm{P} \times \mathrm{M} ; P=0 \cdot 01)$.

\section{Performance at slaughter}

Slaughter was conducted at similar average animal age (Table 3) across experimental treatments $(P=0 \cdot 19)$, consequently the BW measured at the slaughterhouse followed a similar pattern as the ADG with significant effects of the dietary protein level (+5.0\%; $P=0.001)$ and Met content $(+4.2 \% ; P=0.005)$. Hot and cold

Table 2. Animal performance during a 7-month feed efficiency test in young Charolais bulls fed diets formulated at two dietary protein levels (13.5 \% crude protein (Normal) v. $16.5 \%$ crude protein (High)) and two dietary methionine (Met) contents (unbalanced v. balanced in Met (+M)) (Mean values and standard errors)

\begin{tabular}{|c|c|c|c|c|c|c|c|c|}
\hline & \multicolumn{4}{|c|}{ Diets } & \multirow[b]{2}{*}{ SEM } & \multicolumn{3}{|c|}{$P$} \\
\hline & Normal & Normal + M & High & High + M & & Protein & Met & $\mathrm{P} \times \mathrm{M}$ \\
\hline No. of animals & 8 & 8 & 9 & 9 & & & & \\
\hline$N$ intake* $(k g / d)$ & 0.178 & 0.182 & 0.213 & 0.222 & 0.0056 & $<0.001$ & 0.23 & 0.60 \\
\hline ADG $(\mathrm{kg} / \mathrm{d})$ & 1.53 & 1.57 & 1.56 & 1.78 & 0.057 & 0.03 & 0.02 & $0 \cdot 10$ \\
\hline FCE† (kg/kg) & 0.186 & 0.187 & 0.190 & 0.206 & 0.068 & 0.06 & 0.11 & 0.21 \\
\hline NUE‡ (kg/kg) & $23 \cdot 8$ & $24 \cdot 4$ & $20 \cdot 4$ & 21.4 & 0.90 & 0.001 & 0.45 & 0.74 \\
\hline \multicolumn{9}{|c|}{ Ultrasound fat depth§ } \\
\hline Start $(\mathrm{cm})$ & 0.18 & 0.21 & 0.21 & 0.21 & 0.013 & 0.22 & 0.32 & 0.29 \\
\hline End $(\mathrm{cm})$ & 0.46 & 0.50 & 0.54 & 0.57 & 0.020 & 0.001 & $0 \cdot 10$ & 0.86 \\
\hline Gain $\|(\mu \mathrm{m} / \mathrm{d})$ & $15 \cdot 3^{a}$ & $14 \cdot 4^{\mathrm{a}}$ & $15 \cdot 2^{a}$ & $18 \cdot 3^{\mathrm{b}}$ & 0.51 & 0.02 & 0.25 & 0.01 \\
\hline
\end{tabular}

DMI, DM intake; ADG, average daily gain; FCE, feed conversion efficiency; NUE, nitrogen use efficiency.

$\mathrm{a}, \mathrm{b}$ Mean values within a row with unlike superscript letters are significantly different $(P<0.05)$.

* Calculated by multiplying the DMI by the dietary $\mathrm{N}$ content.

† FCE: $100 \times($ average daily gain/DMI).

$\ddagger$ NUE: body $\mathrm{N}$ retention/ $\mathrm{N}$ intake.

$\S$ Average thickness from four different anatomical levels.

$\|$ Gain is calculated as the slope of fat thickness on time (one ultrasound measurement per anatomical level per month; $n 21 / a n i m a l)$. 
Table 3. Slaughter measurements and estimated body composition in young Charolais bulls fed diets formulated at two dietary protein levels (13.5 \% crude protein (Normal) v. $16.5 \%$ crude protein (High)) and two dietary methionine (Met) contents (unbalanced v. balanced in Met (+M))

(Mean values and standard errors)

\begin{tabular}{|c|c|c|c|c|c|c|c|c|}
\hline & \multicolumn{4}{|c|}{ Diet } & \multirow[b]{2}{*}{ SEM } & \multicolumn{3}{|c|}{$P$} \\
\hline & Normal & Normal + M & High & High + M & & Protein & Met & $\mathrm{P} \times \mathrm{M}$ \\
\hline \multicolumn{9}{|l|}{ Measurements at slaughter } \\
\hline Slaughter age (d) & 514 & 507 & 501 & 500 & 7.96 & 0.19 & 0.61 & 0.75 \\
\hline Body weight $(\mathrm{kg})$ & 659 & 673 & 678 & 720 & $9 \cdot 63$ & 0.001 & 0.005 & 0.14 \\
\hline Hot carcass weight (kg) & 398 & 405 & 416 & 432 & $7 \cdot 71$ & 0.006 & $0 \cdot 12$ & 0.51 \\
\hline Cold carcass weight $(\mathrm{kg})$ & 390 & 397 & 408 & 425 & $7 \cdot 60$ & 0.005 & 0.11 & 0.50 \\
\hline Dressing percentage (\%) & $60 \cdot 4$ & $60 \cdot 2$ & $61 \cdot 3$ & $60 \cdot 0$ & 0.61 & 0.61 & 0.21 & 0.41 \\
\hline Conformation score* & $10 \cdot 6$ & $10 \cdot 9$ & $11 \cdot 0$ & $11 \cdot 3$ & 0.23 & 0.07 & 0.79 & 0.20 \\
\hline Carcass fat score $†$ & 5.63 & 5.75 & 5.56 & $6 \cdot 00$ & 0.35 & 0.79 & 0.40 & 0.64 \\
\hline Total internal fat (\% of BW) & 2.63 & 2.57 & $2 \cdot 50$ & $2 \cdot 77$ & $0 \cdot 19$ & 0.83 & 0.53 & 0.36 \\
\hline Total viscera $(\%$ of BW) & $7 \cdot 45$ & $7 \cdot 41$ & $7 \cdot 38$ & $7 \cdot 29$ & $0 \cdot 16$ & 0.55 & 0.87 & 0.69 \\
\hline \multicolumn{9}{|l|}{6 th rib tissue composition $\ddagger(\%)$} \\
\hline Muscle & $70 \cdot 7$ & $70 \cdot 6$ & $72 \cdot 8$ & $69 \cdot 4$ & $1 \cdot 16$ & 0.70 & 0.11 & $0 \cdot 16$ \\
\hline Fat & $10 \cdot 5$ & $11 \cdot 4$ & $10 \cdot 9$ & $13 \cdot 3$ & 0.79 & $0 \cdot 16$ & 0.03 & 0.36 \\
\hline Bone & $14 \cdot 6$ & $13 \cdot 8$ & $12 \cdot 6$ & $12 \cdot 9$ & 0.58 & 0.02 & 0.74 & 0.32 \\
\hline Other§ & $4 \cdot 10$ & 4.03 & 3.60 & $4 \cdot 30$ & 0.305 & 0.72 & 0.27 & 0.20 \\
\hline \multicolumn{9}{|l|}{ Estimated parameters } \\
\hline \multicolumn{9}{|l|}{ Carcass tissue composition $\|$} \\
\hline Muscle $(\mathrm{kg})$ & 292 & 296 & 305 & 312 & $6 \cdot 18$ & 0.02 & 0.39 & 0.77 \\
\hline Muscle (\%) & 73.4 & $73 \cdot 1$ & 73.5 & $72 \cdot 3$ & 0.40 & 0.32 & 0.05 & 0.30 \\
\hline Total adipose tissue $(\mathrm{kg})$ & $52 \cdot 3$ & $54 \cdot 7$ & 54.9 & $62 \cdot 5$ & 1.76 & 0.005 & 0.005 & 0.14 \\
\hline Total adipose tissue (\%) & $13 \cdot 1$ & $13 \cdot 5$ & $13 \cdot 2$ & $14 \cdot 4$ & 0.35 & 0.13 & 0.03 & 0.24 \\
\hline Skeleton (kg) & 53.5 & $54 \cdot 4$ & $55 \cdot 2$ & $57 \cdot 4$ & 0.78 & 0.004 & 0.05 & 0.40 \\
\hline Skeleton (\%) & $13 \cdot 4$ & $13 \cdot 4$ & $13 \cdot 3$ & $13 \cdot 3$ & 0.073 & 0.05 & 0.89 & 0.92 \\
\hline \multicolumn{9}{|l|}{ Chemical body composition } \\
\hline Protein $(\mathrm{kg})$ & 110 & 112 & 115 & 119 & $1 \cdot 80$ & 0.003 & 0.07 & 0.42 \\
\hline Protein (\% of EBW) & $19 \cdot 6$ & $19 \cdot 6$ & $19 \cdot 7$ & $19 \cdot 5$ & 0.11 & 0.80 & 0.30 & 0.38 \\
\hline Lipid (kg) & $79 \cdot 3$ & $81 \cdot 6$ & 81.9 & $93 \cdot 2$ & $3 \cdot 16$ & 0.03 & 0.03 & 0.16 \\
\hline Lipid (\% of EBW) & $14 \cdot 0$ & $14 \cdot 2$ & $14 \cdot 0$ & $15 \cdot 2$ & 0.44 & 0.27 & $0 \cdot 12$ & 0.26 \\
\hline Water $(\mathrm{kg})$ & 350 & 355 & 362 & 374 & $5 \cdot 04$ & 0.03 & 0.07 & 0.42 \\
\hline Water (\% of EBW) & $62 \cdot 0$ & 61.9 & $62 \cdot 0$ & $61 \cdot 1$ & 0.32 & $0 \cdot 18$ & 0.09 & 0.24 \\
\hline Mineral $(\mathrm{kg})$ & 24.4 & 24.7 & $25 \cdot 2$ & $26 \cdot 0$ & 0.33 & 0.003 & 0.07 & 0.42 \\
\hline Mineral (\% of EBW) & $4 \cdot 32$ & $4 \cdot 31$ & 4.31 & $4 \cdot 24$ & 0.022 & $0 \cdot 10$ & 0.07 & 0.21 \\
\hline \multicolumn{9}{|l|}{ Calculated body gains $(\mathrm{kg})$} \\
\hline Body weight & 329 & 343 & 334 & 380 & $10 \cdot 3$ & 0.04 & 0.005 & 0.11 \\
\hline Protein** & $58 \cdot 0$ & $59 \cdot 7$ & $59 \cdot 8$ & $64 \cdot 8$ & 1.94 & 0.08 & 0.08 & 0.39 \\
\hline Lipid $^{\star \star}$ & 49.5 & $52 \cdot 6$ & $49 \cdot 8$ & $63 \cdot 2$ & 2.96 & 0.07 & 0.006 & 0.08 \\
\hline
\end{tabular}

BW, body weight; EBW, empty body weight.

* EU Beef Carcass Classification Scheme scale, where 1 represents the poorest and 15 the best conformation.

$\dagger$ EU Beef Carcass Classification Scheme scale, where 1 represents the leanest and 15 the fattest carcass.

$\ddagger$ After rib dissection $24 \mathrm{~h}$ post-slaughter.

$\S$ Cartilage and nerves.

Estimated from 6th rib dissection ${ }^{(26)}$.

ๆ Estimated from total adipose tissue in carcass + total internal fat ${ }^{(27)}$

${ }_{\star \star}$ Calculated as the difference between the end and start of the feed efficiency test. Composition at the start was estimated from the diameter of subcutaneous adipose cells sampled by biopsy at the start of the experiment test and expressed as \% of EBW ${ }^{(25)}$, whereas composition at the end was estimated from the 6 th rib dissection one ${ }^{(26,27)}$ and expressed as \% of EBW.

carcass weights increased as the dietary protein level increased $(+5.5 \%$ on average; $P \leq 0.006)$ but only numerically as the Met content increased $(+3 \%$ on average; $P=0 \cdot 12$ ). Dressing percentage, carcass conformation and fatness, total internal fat and viscera weight proportions were not affected by dietary treatments $(P>0 \cdot 10)$ except for a tendency $(P=0 \cdot 07)$ for High protein diets to yield higher conformation scores compared with Normal protein diets. The measured tissue composition of the 6th rib was similar across diets except for a greater fat proportion for bulls fed Met-balanced diets $(+15.4 \% ; P=0.02)$ and for a lower bone proportion as diets changed from Normal to High protein $(+1.9 \% ; P=0.02)$.

Carcass total adipose tissue and skeleton weights were increased by dietary Met (+9.3 and $2.9 \%$, respectively;
$P \leq 0 \cdot 05)$, in contrast to carcass muscle weight which was unaffected $(P=0 \cdot 39)$. Consequently, the proportion of total adipose tissue in carcass increased $(+5$ percentage units on average; $P=0.03)$, whereas that of muscle decreased $(-0.8$ percentage units on average; $P=0.05)$ when Met was added to diets. Increasing the dietary protein content increased total adipose tissue, muscle and skeleton weights in carcass $(P \leq 0.02)$ and decreased the proportion of skeleton in carcass $(P=0.05)$. Increasing dietary protein content increased total body protein, lipid, water and mineral weights $(P \leq 0.03)$ but not their proportion $(P \geq 0 \cdot 10)$. Balancing diets with Met improved total body protein, lipid, water and mineral weights $(P \leq 0.07)$ and tended to decrease the body proportions of water and mineral $(P=0.09$ and $0 \cdot 07$, respectively). 
The greater BW gain observed with High $v$. Normal protein diets $(+6 \% ; P=0.04)$ and with Met-balanced $v$. unbalanced diets $(+9 \% ; P=0.005)$ was the consequence of both greater accretion of both body protein $(+5.5 \% ; P=0.08)$ and lipid $(+9.8$ and $+14.5 \%$ for dietary protein and Met content, respectively; $P \leq 0.07)$ mass. However, the improvement in lipid mass accretion as diets were balanced for Met tended to be greater for High $v$. Normal protein diets $(\mathrm{P} \times \mathrm{M}$ interaction; $P \leq 0 \cdot 08)$.

\section{Plasma metabolites and isotopic nitrogen turnover rate}

As shown in Table 4, regardless of the dietary protein level, balancing diets for Met increased concentrations of Asp $(P=0.03)$,
Gln $(P=0.001)$, Glu $(P=0.05)$, Met $(P<0.001)$, Phe $(P=0.07)$, Tau $(P<0.001)$ and Tyr $(P=0.006)$ and decreased those of urea $(P=0.09)$, Gly $(P=0.04)$ and Ser $(P=0.001)$. However, balancing diets for Met increased plasma concentrations of Arg, Asn, His, Ile, Orn, Pro, non-essential AA, essential AA, total AA and Met sulfoxide only at High but not at Normal protein levels $(\mathrm{P} \times \mathrm{M}$ interaction; $P<0 \cdot 05)$.

Plasma $\mathrm{N}$ isotopic kinetics are presented in Table 5. After stopping the ${ }^{15} \mathrm{~N}$-labelled urea administration (similar amount across dietary treatments), the plasma $\delta^{15} \mathrm{~N}$ values were lower as the dietary protein increased $(P=0.004)$ and tended to be higher as the diets were balanced $v$. unbalanced in Met $(P=0.06)$. Increasing the dietary protein and Met content

Table 4. Plasma metabolites measured at different time points in young Charolais bulls fed diets formulated at two dietary protein levels (13.5\% crude protein (Normal) v. $16.5 \%$ crude protein (High)) and two dietary methionine (Met) contents (unbalanced $v$. balanced in Met (+M)) (Mean values and standard errors)

\begin{tabular}{|c|c|c|c|c|c|c|c|c|c|c|c|}
\hline & \multicolumn{4}{|c|}{ Diets } & \multirow[b]{2}{*}{ SEM } & \multicolumn{6}{|c|}{$P$} \\
\hline & Normal & Normal $+\mathrm{M}$ & High & $\mathrm{High}+\mathrm{M}$ & & Time & Protein & Met & $T \times P$ & $\mathrm{~T} \times \mathrm{M}$ & $P \times M$ \\
\hline No. of animals & 8 & 8 & 9 & 9 & & & & & & & \\
\hline Acetate $(\mathrm{g} / \mathrm{l})$ & & & & & 0.032 & 0.04 & 0.43 & 0.35 & 0.14 & 0.89 & 0.87 \\
\hline Day 34 & 0.443 & 0.423 & 0.452 & 0.395 & & & & & & & \\
\hline Day 91 & 0.336 & 0.313 & 0.415 & 0.387 & & & & & & & \\
\hline Day 154 & 0.405 & 0.381 & 0.403 & 0.391 & & & & & & & \\
\hline BHBA $(g / l)$ & & & & & 0.019 & $<0.001$ & 0.85 & 0.78 & 0.04 & 0.59 & 0.75 \\
\hline Day 34 & 0.362 & 0.379 & 0.314 & 0.335 & & & & & & & \\
\hline Day 91 & 0.189 & 0.215 & 0.229 & 0.212 & & & & & & & \\
\hline Day 154 & 0.200 & 0.185 & 0.214 & 0.209 & & & & & & & \\
\hline Glucose (g/l) & & & & & 0.031 & $<0.001$ & 0.03 & 0.88 & 0.91 & 0.50 & 0.51 \\
\hline Day 34 & 0.764 & 0.794 & 0.845 & 0.835 & & & & & & & \\
\hline Day 91 & 0.519 & 0.573 & 0.586 & 0.589 & & & & & & & \\
\hline Day 154 & 0.586 & 0.558 & 0.635 & 0.609 & & & & & & & \\
\hline NEFA $(g / l)$ & & & & & 0.018 & 0.02 & 0.69 & 0.24 & 0.62 & 0.65 & 0.50 \\
\hline Day 34 & 0.127 & 0.094 & 0.114 & 0.093 & & & & & & & \\
\hline Day 91 & 0.077 & 0.054 & 0.087 & 0.080 & & & & & & & \\
\hline Day 154 & 0.116 & 0.102 & 0.108 & 0.116 & & & & & & & \\
\hline Urea $(g / l)$ & & & & & 0.010 & $<0.001$ & 0.001 & 0.09 & 0.83 & $0 \cdot 10$ & 0.10 \\
\hline Day 34 & 0.147 & 0.131 & 0.255 & 0.179 & & & & & & & \\
\hline Day 91 & 0.053 & 0.063 & 0.165 & 0.125 & & & & & & & \\
\hline Day 154 & 0.101 & 0.110 & 0.217 & 0.157 & & & & & & & \\
\hline Amino acids ( $\mu \mathrm{M})$ & & & & & & & & & & & \\
\hline Ala & & & & & 11.8 & $<0.001$ & 0.16 & 0.12 & 0.65 & $0 \cdot 10$ & 0.17 \\
\hline Day 91 & 240 & 260 & 213 & 258 & & & & & & & \\
\hline Day 154 & 209 & 189 & 163 & 189 & & & & & & & \\
\hline Arg & & & & & 4.56 & 0.56 & $<0.001$ & 0.08 & 0.02 & 0.67 & 0.02 \\
\hline Day 91 & $121^{\mathrm{a}}$ & $112^{\mathrm{a}}$ & $136^{a}$ & $165^{b}$ & & & & & & & \\
\hline Day 154 & 123 & 123 & 133 & 148 & & & & & & & \\
\hline Asn & & & & & 1.61 & $<0.001$ & 0.08 & 0.03 & 0.24 & 0.62 & 0.006 \\
\hline Day 91 & $38.2^{\mathrm{a}}$ & $37.9^{\mathrm{a}}$ & $38.3^{\mathrm{a}}$ & $48 \cdot 2^{b}$ & & & & & & & \\
\hline Day 154 & $34 \cdot 1$ & 31.3 & 29.7 & 39.0 & & & & & & & \\
\hline Asp & & & & & 0.49 & 0.004 & 0.01 & 0.005 & 0.37 & 0.84 & 0.42 \\
\hline Day 91 & 8.96 & 9.67 & $7 \cdot 14$ & 8.82 & & & & & & & \\
\hline Day 154 & 7.39 & $8 \cdot 31$ & 6.56 & 7.76 & & & & & & & \\
\hline $\mathrm{Cit}^{\star}$ & & & & & 2.51 & $<0.001$ & 0.27 & 0.27 & 0.92 & 0.19 & 0.33 \\
\hline Day 91 & 91.5 & 74.5 & 87.7 & 88.0 & & & & & & & \\
\hline Day 154 & $76 \cdot 1$ & 72.5 & 80.8 & $79 \cdot 8$ & & & & & & & \\
\hline Gln & & & & & $18 \cdot 2$ & 0.05 & 0.66 & 0.001 & 0.09 & 0.50 & 0.19 \\
\hline Day 91 & 402 & 422 & 410 & 474 & & & & & & & \\
\hline Day 154 & 388 & 432 & 355 & 432 & & & & & & & \\
\hline Glu & & & & & 4.76 & $<0.001$ & 0.001 & 0.05 & 0.07 & 0.20 & 0.46 \\
\hline Day 91 & $94 \cdot 2^{\mathrm{a}}$ & $115^{\mathrm{b}}$ & $76 \cdot 6^{a}$ & $84 \cdot 6^{a}$ & & & & & & & \\
\hline Day 154 & $70 \cdot 2$ & $75 \cdot 8$ & 59.7 & 64.1 & & & & & & & \\
\hline Gly & & & & & $17 \cdot 0$ & $<0.001$ & 0.002 & 0.04 & 0.17 & 0.45 & 0.16 \\
\hline Day 91 & 569 & 463 & 431 & 420 & & & & & & & \\
\hline Day 154 & 404 & 352 & 336 & 311 & & & & & & & \\
\hline
\end{tabular}


Table 4. (Continued)

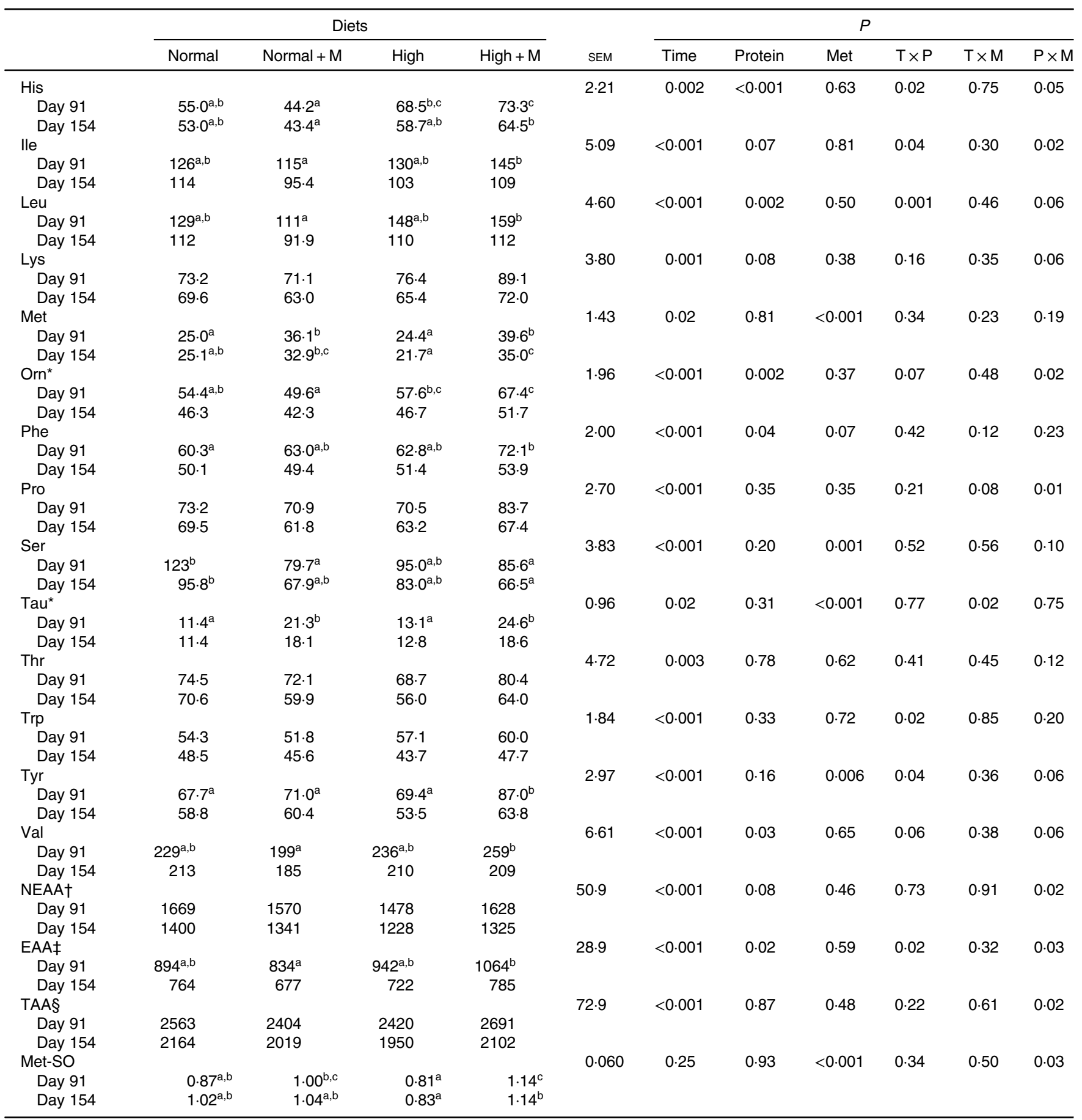

BHBA, $\beta$-hydroxy-butyrate; NEAA, non-essential AA; AA, amino acid; EAA, essential AA; TAA, total AA; Met-SO, methionine sulfoxide.

a,b,c Mean values within a row with unlike superscript letters are significantly different $(P<0.05)$.

${ }^{*}$ Non-proteinogenic AA.

† NEAA $=\mathrm{Ala}+\mathrm{Arg}+\mathrm{Asn}+\mathrm{Asp}+\mathrm{Gln}+\mathrm{Glu}+\mathrm{Gly}+\mathrm{Pro}+$ Ser.

$\ddagger \mathrm{EAA}=\mathrm{His}+\mathrm{Ile}+\mathrm{Leu}+\mathrm{Lys}+$ Met $+\mathrm{Phe}+\mathrm{Thr}+\mathrm{Trp}+\mathrm{Tyr}+\mathrm{Val}$.

$\S \mathrm{TAA}=\mathrm{NEAA}+\mathrm{EAA}$.

promoted a greater isotopic $\mathrm{N}$ turnover rate $(\mathrm{k})$ measured in plasma proteins ( +9 and $+4 \%$, respectively; $P \leq 0.05)$. At the isotopic equilibrium ( $142 \mathrm{~d}$ after stopping the ${ }^{15} \mathrm{~N}$-labelled urea administration), plasma $\delta^{15} \mathrm{~N}$ values were only affected by the dietary protein content, being lower in High $v$. Normal diets $(P=0.01)$. The difference in $\delta^{15} \mathrm{~N}$ values between plasma proteins at equilibrium and the diet (called isotopic $\mathrm{N}$ discrimination; $\Delta^{15} \mathrm{~N}_{\text {animal-diet }}$ ) tended to be higher as the dietary protein 
Table 5. Isotopic ${ }^{15} \mathrm{~N}$ kinetics in plasma proteins from young Charolais bulls fed diets formulated at two dietary protein levels ( $13.5 \%$ crude protein (Normal) $v$. $16.5 \%$ crude protein (High) and two dietary methionine (Met) contents (unbalanced $v$. balanced through the use of supplemental rumen-protected Met (+M)) (Mean values and standard errors)

\begin{tabular}{|c|c|c|c|c|c|c|c|c|}
\hline & \multicolumn{4}{|c|}{ Diets } & \multirow[b]{2}{*}{ SEM } & \multicolumn{3}{|c|}{$P$} \\
\hline & Normal & Normal + M & High & $\mathrm{High}+\mathrm{M}$ & & Protein & Met & $P \times M$ \\
\hline No. of animals & 8 & 8 & 9 & 9 & & & & \\
\hline Diet $\delta^{15} \mathrm{~N}(\% \circ)$ & 4.07 & 4.07 & 3.66 & 3.66 & & & & \\
\hline Plasma initial $\delta^{15} \mathrm{~N}(\% \circ)$ & $16 \cdot 0$ & $16 \cdot 8$ & $14 \cdot 2$ & $15 \cdot 0$ & 0.27 & 0.004 & 0.06 & 0.62 \\
\hline Plasma k (per d) & 0.039 & 0.042 & 0.043 & 0.046 & 0.0015 & 0.01 & 0.02 & 0.45 \\
\hline Plasma asymptotic $\delta^{15} \mathrm{~N}(\% \circ)$ & $6 \cdot 68$ & 6.69 & 6.54 & 6.38 & 0.045 & 0.01 & 0.47 & 0.28 \\
\hline$\Delta^{15} \mathrm{~N}_{\text {animal-diet }}(\%)$ & $2 \cdot 60$ & $2 \cdot 62$ & 2.89 & $2 \cdot 72$ & 0.010 & 0.06 & 0.43 & 0.38 \\
\hline
\end{tabular}

content increased $(P=0.06)$ but did not differ between diets balanced and unbalanced for Met $(P>0 \cdot 10)$.

\section{Discussion}

\section{In vivo performance}

As observed in the present experiment, the addition of rumenprotected Met to diets meeting or exceeding theoretical animal metabolisable protein requirements may still improve growth performance providing the dietary metabolisable protein is deficient in this particular $\mathrm{AA}^{(31)}$. Rumen microbial protein contains low Met levels (Lys:Met ratio close to $3 \cdot 5^{(32)}$ ) in relation to animal requirements (Lys:Met ratio close to 2.9 for dairy cattle ${ }^{(7)}$ ). Thus, Met has been proposed to be the first-limiting AA for ruminants fed protein mainly from the microbial origin ${ }^{(5,3)}$ and is the main limiting AA in growing beef cattle fed high-forage diets ${ }^{(8,9)}$.

Growth responses to Met supplementation have not been consistent across studies ${ }^{(29,34,35)}$. Discrepancies seem to stem from differences in the quality of the basal diet (high $v$. low in rumen degradable protein $\left.{ }^{(34)}\right)$ and the AA profile of rumen bypass protein ${ }^{(36)}$ used to complement the diet when the microbial protein supply does not meet animals' AA requirements. According to our feed values, the two grass-silage basal diets used in this study were deficient in Met in regard to recommendations for lactating dairy cows (Lys:Met ratio close to $3.5 \mathrm{v}$. $\left.2 \cdot 9 \%^{(7)}\right)$. This, together with the fact that we used animals with a high growth potential (ADG $>1.6 \mathrm{~kg} / \mathrm{d}$ on average), should have favoured the response to Met supplementation. In such conditions, our results showed that Met-balanced diets promoted a greater BW gain compared with Met-unbalanced diets, supporting the concept of Met limiting or co-limiting the productivity of cattle fed grass silage diets ${ }^{(29)}$. However, this improvement in animal performance tended to be greater with High $(+14 \%) v$. Normal $(+2 \%)$ protein diets, rejecting our initial hypothesis. Indeed, our results confirm previous findings showing a synergy between rumen-protected Met and protein supplements supplying large amounts of essential AA but low levels of Met as blood or meat meal ${ }^{(31,37)}$. In the present study, the increase in dietary protein content was achieved mostly by the substitution of wheat grains by formaldehyde-treated soyabean meal (Table 1). Formaldehyde-treated soyabean meal supplies relatively high amounts of rumen bypass protein (as revealed by the lower enzymatic CP degradability (parameter allowing to estimate the rumen protein degradation in the INRA feeding system $^{(7)}$ ) in High $v$. Normal protein diets; Table 1), but it is known to have a very low content of sulfur $\mathrm{AA}^{(38)}$. Therefore, our data confirm that the growth response to Met supplementation may be improved when a basal diet containing low rumen bypass protein ( $2 \% \mathrm{DM}$ basis in the present study) is supplemented with rumen bypass protein containing low Met content ${ }^{(9)}$. Interestingly, similar to our results, a recent metaanalysis using thirty-five studies with dairy cattle found that the milk yield response to rumen-protected Met was surprisingly higher in animals with no predicted AA deficiency (positive metabolisable protein balance) compared with those with a predicted Met deficiency ${ }^{(39)}$. Alternatively, results from the present study may suggest that INRA protein recommendation could underestimate protein requirements in fast growing cattle or overestimate the metabolisable protein supplied by high-forage diets. If so, this would mean that co-limiting AA other than Met could be present in our Normal protein diet but not in our High protein diet.

Greater BW and protein gains observed when High protein diets were balanced $v$. unbalanced in Met $(+9 \cdot 0$ and $+5.5 \%$, respectively; Table 3) seemed to be the consequence of both a greater, but not significant, feed intake (+4\%) and FCE (+8\%). Improvements in DM intake with Met supplementation have been documented in other ruminant studies ${ }^{(40-42)}$ and confirmed through meta-analysis when Met is provided as Smartamine $\mathrm{M}^{(43)}$ as in the present experiment. Although the underlying mechanism is not completely understood, higher energy requirements associated with greater growth rates could explain to some extent this finding. The higher FCE could be driven by a higher efficiency of $\mathrm{N}$ retention in ruminants receiving diets supplemented with $\mathrm{Met}^{(44-46)}$. The overall NUE for the whole experimental period only increased by $<5 \%$ between balanced and unbalanced Met diets at high protein levels. However, it should be noted that NUE calculations in the present study were based on estimations of body composition mostly from the 6th rib composition ${ }^{(26,27)}$ rather than direct measurement. To overcome this limitation other indicators were analysed and, as further discussed here, they also pointed to a moderate NUE improvement when High protein diets were balanced in Met.

Although a positive impact of supplying limiting AA on performance of growing-fattening cattle has been reported in several studies $^{(12,31,47)}$, the concept of supplying limiting AA to growing-fattening cattle is rarely applied in the beef industry. Our results confirm the necessity of evaluating by doseresponse studies the requirements of Met for fattening young 
bulls with a high growth potential to extend the concept of limiting AA, which is very developed and used in swine and dairy cattle nutrition, to growing ruminants mainly fed high-forage diets. In addition, a cost-benefit analysis should be performed in the future to determine whether use of ruminally protected AA could translate into a greater farm profitability.

\section{Performance at slaughter}

The lack of significant effects of balancing diets for Met on carcass weights ( $+3 \%$ on average), although significantly affecting the $\mathrm{BW}$ at slaughter $(+4 \%$ on average), could be partially explained by the slightly higher intake promoted by the Metsupplemented diets. Indeed, the measured digestive content of animals receiving Met-balanced diets was higher than those with Met-unbalanced diets $(+10 \% ; P=0 \cdot 02$; data not shown). Moreover, this study was designed to determine the effect of Met-balanced diets on growth performance. Given the observed effect size of Met on carcass weight $(11 \mathrm{~kg})$ and a SD of $22 \cdot 8 \mathrm{~kg}$, sixty-eight animals (seventeen animals/treatment) would be needed to detect a significant difference $(\alpha=0.05 ; \beta=0.80)$ in that variable. Unfortunately, there is a lack in the literature of catthe studies evaluating the effect of rumen-protected Met on animal performance at the slaughterhouse. Measured fat proportion from the 6th rib and the resulting estimated lipid body gain confirmed in vivo ultrasound back depth results showing a greater fat deposition when Met-balanced diets were formulated at High protein levels. Increasing fat deposition in response to Met supplementation has also been reported in sheep ${ }^{(40)}$. However, an opposite effect was also found in growing lambs ${ }^{(41)}$ in agreement with different studies in poultry ${ }^{(48,49)}$ suggesting that higher hepatic concentration of carnitine, synthesised from Met and Lys, can facilitate fatty acid oxidation in the liver. Some unknown interfering factors related to diets or animal physiological state could explain contradictory results. In the present study, changes in fat deposition with Met supplementation could be the consequence of a concomitant increase in $\mathrm{BW}$ gain because the amount of lipid deposited daily is proportional to the average daily gain raised to the power of $1 \cdot 8^{(7)}$. However, because animals were not slaughtered at a fixed BW, it is not possible in our conditions to dissociate a greater body lipid content from a greater BW. Thus, greater animal growth rates likely led to a lower protein:fat ratio in the body gain. In this sense, our results confirm previous findings in growing ruminants reporting lower muscle proportion in carcasses with Met-balanced (Lys/ Met $=3.0) v$. unbalanced $($ Lys $/$ Met $=3.4) \operatorname{diets}^{(50)}$.

\section{Nitrogen metabolism}

The increase observed in plasma Met concentration (+50\%) when diets were supplemented with Met agrees with previous studies $^{(29,51,52)}$ and confirms that metabolisable Met supply was improved when high-forage diets were supplemented with rumen-protected Met. This increase was accompanied by concomitant greater plasma concentrations of other metabolites resulting from Met metabolism. Taurine, derived from cysteine following Met catabolism through the trans-sulfuration pathway, increased after Met supplementation in agreement with other ruminant studies ${ }^{(53,54)}$. Moreover, two other AA metabolically linked to Met utilisation, Gly and Ser, decreased their plasma concentrations in Met-balanced diets. Indeed, lower Gly and Ser plasma concentrations can be explained by their role in the conversion of Met to homocysteine and further to cysteine during trans-sulfuration reactions ${ }^{(55)}$. Finally, higher plasma Met sulfoxide, a major product of both free and protein-bound Met oxidation by reactive oxygen and nitrogen species ${ }^{(56)}$, may reflect a higher availability of Met in our Met-balanced diets. Alternatively, all these data could indicate that the optimum level of Met supplementation was exceeded with our Met-balanced diets, in agreement with our estimated dietary metabolisable Met concentration exceeding the theoretical dairy cow requirement $(2.6 \%$ of metabolisable protein on average $v .2 .4 \%$ of metabolisable protein; Table 1). However, without a doseresponse study, it is quite speculative to conclude that the optimum level of Met has been exceeded in our conditions and more research is warranted to establish the optimum level of Met supply for growing beef cattle.

Decreased plasma concentrations of branched-chain AA (Ile, Leu and Val), the most abundant AA in muscle, are often reported in the literature when cattle are supplemented with $\mathrm{Met}^{(54,55)}$. Although this is usually explained by greater AA utilisation when protein synthesis is improved after removing the Met deficiency, the catabolism of branched-chain AA could also be enhanced by excess $\mathrm{Met}^{(54)}$. Unexpectedly, an interaction between the dietary protein and Met content was noted for the three branched-chain AA (Ile, Leu and Val; $P \leq 0.06$ ), indicating lower plasma concentration when Met supplementation was applied to Normal protein diets $(-14 \%$ on average) but higher (or similar) when applied to High protein diets ( $+6 \%$ on average). A similar pattern, although non-significant, was also observed with lactating ewes fed rumen-protected Met and Lys at two protein levels ${ }^{(53)}$. Moreover, the same interaction between dietary protein and Met content was also observed for many other AA such as Arg, Asn, His, Orn, Pro and nonessential AA, essential AA and total AA, likely suggesting that metabolisable protein supply could be somehow deficient in our Normal protein diets, thereby limiting the potential response of supplementary Met. This last point is in agreement with the fact that the improvement of animal performance in Met-balanced diet was lower in Normal $v$. High protein diets. Based on plasma AA profile, it can be concluded that: (i) Metabolisable Met supply was greatly increased when animals were fed diets supplemented with rumen-protected Met, likely enhancing the plasma pool of sulphur compounds, (ii) Normal protein diets without Met balancing were limited by Met supply but thereafter co-limited by other essential AA, suggesting a metabolisable protein supply slightly under requirements, and (iii) High protein diets without Met balancing were only limited by Met supply. These conclusions based on plasma AA profile are in agreement with the observed trend for a greater effect of Met balancing on growth performance in High $v$. Normal protein diets.

We observed on average (from three analysed time points) a trend for Met-balanced diets to have lower urea plasma levels, with the decrease being more pronounced in High protein diets $(-34 \%$ on average), and this was consistent over time. This would suggest a more efficient use of feed $\mathrm{N}$ when Met-balanced 
diets were formulated at High protein levels ${ }^{(57)}$. Lower plasma or blood urea concentrations have been reported when diets were supplemented with rumen-protected $\mathrm{Met}^{(54,58,59)}$, but other studies failed to observe any difference ${ }^{(45,60)}$.

Results from the minimally invasive approach here tested for measuring the isotopic turnover rate in animal proteins indicate a higher fractional synthesis rate of plasma proteins (plasma $\mathrm{k}$ value; Table 5) in Met-balanced diets regardless of the dietary protein content. The rate at which animal proteins incorporate a new dietary isotopic signature depends on both the metabolic tissue replacement and growth ${ }^{(61)}$ and has been demonstrated by mechanistic models ${ }^{(62,63)}$ to reflect changes in the fractional protein synthesis rate of that particular pool. Although we should be careful with interpretations based on this new proxy ${ }^{(17)}$ and when extrapolating results from plasma protein to whole-body proteins, this may indicate that protein synthesis is enhanced in Met-balanced diets and perhaps contributing to the higher $\mathrm{N}$ retention. Interestingly, the plasma initial ${ }^{15} \mathrm{~N}$ values just after stopping the ${ }^{15} \mathrm{~N}$-urea administration (day 0 ) tended to be higher in Met-balanced ( $15.7 \%$ on average) $v$. unbalanced ( $15.1 \%$ on average) diets. This finding agrees with a higher fractional synthesis rate of plasma proteins since greater initial isotopic values before the ${ }^{15} \mathrm{~N}$ depletion indicate that the rate at which the ${ }^{15} \mathrm{~N}$-AA from labelled microbial protein are assimilated by animal proteins were higher with Met-balanced diets. The same rationale does not apply however when comparing Normal $v$. High protein diets. While a higher fractional synthesis rate (plasma $\mathrm{k}$ value) was observed with High protein diets, the greater (unlabelled) $\mathrm{N}$ intake associated with High protein diets also promoted a greater dilution of the ${ }^{15} \mathrm{~N}$-labelled urea and thus lower plasma initial ${ }^{15} \mathrm{~N}$ values. Wessels et al. ${ }^{(12)}$, applying a different isotopic method, also found that protein synthesis tended to increase in response to supplementation with limiting AA.

Assuming that our plasma ${ }^{15} \mathrm{~N}$ values after $106 \mathrm{~d}$ are at the isotopic equilibrium ${ }^{(64)}$, the asymptotic plasma ${ }^{15} \mathrm{~N}$ values can be considered close to the natural ${ }^{15} \mathrm{~N}$ abundance in animal proteins. The difference in the natural ${ }^{15} \mathrm{~N}$ abundance between the animal proteins and the consumed $\operatorname{diet}\left(\Delta^{15} \mathrm{~N}_{\text {animal-diet }}\right)$ has been proposed as a biomarker of NUE, with lower values generally observed in more efficient animals ${ }^{(65)}$. Although no significant effects of dietary Met content were found, a numerically lower $(-6 \%) \Delta{ }^{15} \mathrm{~N}_{\text {animal-diet }}$ was noted for the unbalanced $v$. balanced High protein diet, indicating a lower $\mathrm{NUE}^{(18)}$. When taken together, NUE, plasma urea concentration, $\mathrm{N}$ isotopic turnover in plasma proteins and $\Delta^{15} \mathrm{~N}_{\text {animal-diet }}$ suggest a slightly better use of AA in Met-balanced diets, especially at High protein levels.

\section{Conclusions}

Like in other livestock animals, the principle of a specific AA limiting the animal productivity also applies to growing beef cattle. Balancing high-forage diets for Met supply improved growth rate in fast-growing Charolais bulls, with a greater effect when diets were formulated at High $v$. Normal protein content. Metabolic changes, such as a better plasma AA profile and some indicators suggesting a greater NUE and N retention, were observed when diets were balanced for Met. Our results justify the need for integrating AA recommendations in growing ruminants. Further studies should confirm the interaction between the dietary metabolisable protein and Met content and establish the optimum predicted concentrations of Met in metabolisable protein when growing cattle are fed different types of diets.

\section{Acknowledgements}

The authors would like to thank Vincent Largeau, Céline Chantelauze and the staff of Herbipôle for their great technical assistance during this study.

Adisseo is acknowledged for financially supporting this study.

The authors' contributions are as follows: G. C.-H. and L. B. formulated the research question and with I. O.-M. and E. T. designed the experimental protocol. In vivo data were analysed by B. S. with G. C.-H. and L. B. All the statistical analysis were performed by G. C.-H. While the interpretation of results were conducted by G. C.-H., I. O.-M. and L. B. All authors were involved in the preparation of the manuscript and approved the final manuscript. G. C.-H. had primary responsibility for the final content.

L. B. is employed by Adisseo France SAS which commercialises Smartamine ${ }^{\circledR}$ used in this experiment. The remaining authors declare that the research was conducted in the absence of any commercial or financial relationship that could be construed as a potential conflict of interest.

\section{References}

1. Makkar HPS \& Beever D (2013) Optimization of feed use efficiency in ruminant production systems. In Proceeding of the FAO Symposium, 27 November 2012, Bangkok, Thailand. FAO Animal Production and Health Proceedings, No 16. Rome: FAO and Asian-Australasian Association of Animal Production Societies.

2. Tolkamp B, Wall E, Roehe R, et al. (2010) Review of nutrient efficiency in different breeds of farm livestock. Report prepared for the Department of Environment, Food and Rural Affairs, London, UK. http://sciencesearch.defra.gov.uk/Document. aspx?Document=FinalReportIF0183.doc (accessed October 2019).

3. Wilkinson JM (2011) Re-defining efficiency of feed use by livestock. Animal 5, 1014-1022.

4. Titgemeyer EC \& Löest CA (2001) Amino acid nutrition: demand and supply in forage-fed ruminants. J Anim Sci 79, E180-E189.

5. Richardson CR \& Hatfield EE (1978) The limiting amino acids in growing cattle. J Anim Sci 46, 740-745.

6. Storm E \& Orskov ER (1984) The nutritive value of rumen micro-organisms in ruminants. 4. The limiting amino acids of microbial protein in growing sheep determined by a new approach. BrJ Nutr 52, 613-620.

7. INRA (2018) INRA Feeding System for Ruminants. Wageningen, the Netherlands: Wageningen Academic Publishers.

8. Nimrick K, Hatfield EE, Kaminski J, et al. (1970) Quantitative assessment of supplemental amino acid needs for growing lambs fed urea as the sole nitrogen source. J Nutr 100, 1301-1306.

9. Titgemeyer EC \& Merchen NR (1990) The effect of abomasal methionine supplementation on nitrogen retention of 
growing steers postruminally infused with casein or nonsulfurcontaining amino acids. J Anim Sci 68, 750-757.

10. Geay Y \& Robelin J (1979) Variation of meat production capacity in cattle due to genotype and level of feeding: genotypenutrition interaction. Livest Prod Sci 6, 263-276.

11. Oke BO, Loerch SC \& Deetz LE (1986) Effects of rumenprotected methionine and lysine on ruminant performance and nutrient metabolism. J Anim Sci 62, 1101-1112.

12. Wessels RH, Titgemeyer EC \& St. Jean G (1997) Effect of amino acid supplementation on whole-body protein turnover in Holstein steers. J Anim Sci 75, 3066-3073.

13. Graulet B, Richard C \& Robert JC (2005) Methionine availability in plasma of dairy cows supplemented with methionine hydroxy analog isopropyl ester. J Dairy Sci $\mathbf{8 8}$, 3640-3649.

14. Carleton SA \& Del Rio CM (2005) The effect of coldinduced increased metabolic rate on the rate of ${ }^{13} \mathrm{C}$ and ${ }^{15} \mathrm{~N}$ incorporation in house sparrows (Passer domesticus) Oecologia 144, 226-232.

15. MacAvoy SE, Macko SA \& Arneson LS (2005) Growth versus metabolic tissue replacement in mouse tissues determined by stable carbon and nitrogen isotope analysis. Can J Zool $\mathbf{8 3}$, 631-641.

16. Abimorad EG, Ducatti C, Castellani D, et al. (2014) The use of stable isotopes to investigate the effects of supplemental lysine and methionine on protein turnover and amino acid utilization in pacu, Piaractus mesopotamicus, juveniles. Aquaculture 433, 119-124.

17. Cantalapiedra-Hijar G, Fouillet H, Chantelauze C, et al. (2020) The isotopic nitrogen turnover rate as a proxy to evaluate in the long-term the protein turnover in growing ruminants. J Agric Sci (Epublication ahead of print version 20 March 2020).

18. Cantalapiedra-Hijar G, Ortigues-Marty I, Sepchat B, et al. (2015) Diet-animal fractionation of nitrogen stable isotopes reflects the efficiency of nitrogen assimilation in ruminants. Br J Nutr 113, 1158-1169.

19. Van Soest PV, Robertson JB \& Lewis BA (1991) Methods for dietary fiber, neutral detergent fiber, and nonstarch polysaccharides in relation to animal nutrition. $J$ Dairy Sci $\mathbf{7 4}$, 3583-3597.

20. Aufrère J \& Cartailler D (1988) Mise au point d'une méthode de laboratoire de prévision de la dégradabilité des protéines alimentaires des aliments concentrés dans le rumen (Development of a laboratory method for predicting the degradability of dietary proteins in rumen-based foods). Ann Zootech 37, 255-270.

21. Aufrère J (1982) Etude de la prévision de la digestibilité des fourrages par une méthode enzymatique (Study of the forecast of the digestibility of fodder by an enzymatic method). Ann Zootech 31, 111-130.

22. Martinez del Rio CMD \& Carleton SA (2012) How fast and how faithful: the dynamics of isotopic incorporation into animal tissues. J Mammal 93, 353-359.

23. Pinheiro JC \& Bates DM (2000) Linear mixed-effects models: basic concepts and examples. In Mixed-Effects Models in S and S-Plus, pp. 3-56. New York: Springer.

24. R Development Core Team (2009) $R$ : A Language and Environment for Statistical Computing. Vienna: R Foundation for Statistical Computing. http://www.R-project.org

25. Garcia F \& Agabriel J (2008) CompoCow: a predictive model to estimate variations in body composition and the energy requirements of cull cows during fattening. J Agric Sci $\mathbf{1 4 6}$ 251-265.

26. Robelin J \& Geay Y (1975) Estimation de la composition de la carcasse des taurillons a partir de la composition de la 6eme cote (Estimation of carcass composition of young bulls from the composition of the 6th rib). In Bulletin Technique CRZV Theix-INRA, vol. 22, pp. 41-44. Vannes: Centre de Recherches Zootechniques et Veterinaires de Theix.

27. Robelin J \& Geay Y (1978) Estimation de la composition chimique du corps entier des bovins partir du poids des depots adipeux totaux (Estimation of the chemical composition of the whole body of cattle from the weight of total fat deposits). Ann Zootech 27, 159-167.

28. Kadam P \& Bhalerao S (2010) Sample size calculation. Int J Ayurveda Res 1, 55-57.

29. Veira DM, Seoane JR \& Proulx JG (1991). Utilization of grass silage by growing cattle: effect of a supplement containing ruminally protected amino acids. J Anim Sci 69, 4703-4709.

30. Meale SJ, Morgavi DP, Cassar-Malek I, et al. (2017) Exploration of biological markers of feed efficiency in young bulls. J Agric Food Chem 65, 9817-9827.

31. Klemesrud MJ, Klopfenstein TJ \& Lewis AJ (2000) Metabolizable methionine and lysine requirements of growing cattle. J Anim Sci 78, 199-206.

32. Sok M, Ouellet DR, Firkins JL, et al. (2017) Amino acid composition of rumen bacteria and protozoa in cattle. J Dairy Sci $\mathbf{1 0 0}$, $5241-5249$

33. Storm E \& Orskov ER (1984) The limiting amino acids of microbial protein in growing sheep determined by a new approach. Br J Nutr 52, 613-620.

34. Hussein HS \& Berger LL (1995) Feedlot performance and carcass characteristics of Holstein steers as affected by source of dietary protein and level of ruminally protected lysine and methionine. J Anim Sci 73, 3503-3509.

35. Tripp MW, Hoagland TA, Dahl GE, et al. (1998) Methionine and somatotropin supplementation in growing beef cattle. J Anim Sci 76, 1197-1203.

36. Merchen NR \& Titgemeyer EC (1992) Manipulation of amino acid supply to the growing ruminant. J Anim Sci 70, 3238-3247.

37. Titgemeyer EC, Merchen NR \& Berger LL (1989) Evaluation of soybean meal, corn gluten meal, blood meal and fish meal as sources of nitrogen and amino acids disappearing from the small intestine of steers. J Anim Sci 67, 262-275.

38. Erasmus LJ, Botha PM, Cruywagen CW, et al. (1994) Amino acid profile and intestinal digestibility in dairy cows of rumenundegradable protein from various feedstuffs. J Dairy Sci $\mathbf{7 7}$, 541-551.

39. Patton RA (2010) Effect of rumen-protected methionine on feed intake, milk production, true milk protein concentration, and true milk protein yield, and the factors that influence these effects: a meta-analysis. J Dairy Sci 93, 2105-2118.

40. Mata G, Masters DG, Chamberlain NL, et al. (1997) Production and glutathione responses to rumen-protected methionine in young sheep grazing dry pastures over summer and autumn. Aust J Agric Res 48, 1111-1120.

41. Wiese SC, White CL, Masters DG, et al. (2003) The growth performance and carcass attributes of Merino and Poll Dorset $\times$ Merino lambs fed rumen-protected methionine (Smartamine ${ }^{\circledR}-$ M). Aust J Agr Res 54, 507-513.

42. Broderick GA, Stevenson MJ \& Patton RA (2009) Effect of dietary protein concentration and degradability on response to rumen-protected methionine in lactating dairy cows. J Dairy Sci 92, 2719-2728.

43. Zanton GI, Bowman GR, Vázquez-Añón M, et al. (2014) Metaanalysis of lactation performance in dairy cows receiving supplemental dietary methionine sources or postruminal infusion of methionine. J Dairy Sci 97, 7085-7101.

44. Matras JPRL, Preston RL \& Bartle SJ (2000) Influence of continuous intravenous lysine and methionine infusion on N-balance in growing sheep fed diets that differ in ruminal degradable protein. J Anim Feed Sci 9 , 81-90. 
45. Archibeque SL, Burns JC \& Huntington GB (2002) Nitrogen metabolism of beef steers fed endophyte-free tall fescue hay: effects of ruminally protected methionine supplementation. J Anim Sci 80, 1344-1351.

46. Chen ZH, Broderick GA, Luchini ND, et al. (2011) Effect of feeding different sources of rumen-protected methionine on milk production and N-utilization in lactating dairy cows. J Dairy Sci 94, 1978-1988.

47. Montaño MF, Chirino JO, Latack BC, et al. (2019) Influence of supplementation of growing diets enriched with rumenprotected methionine and lysine on feedlot performance and characteristics of digestion in Holstein steer calves. Appl Anim Sci 35, 318-324.

48. Rostagno HS \& Pack M (1996) Can betaine replace supplemental DL-methionine in broiler diets? J Appl Poultry Res 5, $150-154$.

49. Zhan XA, Li JX, Xu ZR, et al. (2006) Effects of methionine and betaine supplementation on growth performance, carcass composition and metabolism of lipids in male broilers. Br Poultry Sci $\mathbf{4 7}, 576-580$.

50. Prado IN, Campo MM, Muela E, et al. (2015) Effects of castration age, protein level and lysine/methionine ratio in the diet on colour, lipid oxidation and meat acceptability of intensively reared Friesian steers. Animal 9, 1423-1430.

51. Lee C, Hristov AN, Cassidy TW, et al. (2012) Rumen-protected lysine, methionine, and histidine increase milk protein yield in dairy cows fed a metabolizable protein-deficient diet. J Dairy Sci 95, 6042-6056.

52. Torrentera N, Carrasco R, Salinas-Chavira J, et al. (2017) Influence of methionine supplementation of growing diets enriched with lysine on feedlot performance and characteristics of digestion in Holstein steer calves. Asian-Australas J Anim Sci 30, $42-50$.

53. Lynch GP, Elsasser TH, Jackson C Jr, et al. (1991) Nitrogen metabolism of lactating ewes fed rumen-protected methionine and lysine. J Dairy Sci 74, 2268-2276.

54. Blum JW, Bruckmaier RM \& Jans F (1999) Rumen-protected methionine fed to dairy cows: bioavailability and effects on plasma amino acid pattern and plasma metabolite and insulin concentrations. J Dairy Sci 82, 1991-1998.
55. Campbell CG, Titgemeyer EC \& St-Jean G (1996) Efficiency of D- vs L-methionine utilization by growing steers. J Anim Sci 74, 2482-2487.

56. Lee BC \& Gladyshev VN (2011) The biological significance of methionine sulfoxide stereochemistry. Free Radic Biol Med $\mathbf{5 0}$, 221-227.

57. Kohn RA, Dinneen MM \& Russek-Cohen E (2005) Using blood urea nitrogen to predict nitrogen excretion and efficiency of nitrogen utilization in cattle, sheep, goats, horses, pigs, and rats. J Anim Sci 83, 879-889.

58. Williams JE, Newell SA, Hess BW, et al. (1999) Influence of rumen-protected methionine and lysine on growing cattle fed forage and corn based diets. J Prod Agric 12, 696-701.

59. Bach A, Huntington GB \& Stern MD (2000) Response of nitrogen metabolism in preparturient dairy cows to methionine supplementation. J Anim Sci 78, 742-749.

60. Waggoner JW, Loest CA, Mathis CP, et al. (2009) Effects of rumen-protected methionine supplementation and bacterial lipopolysaccharide infusion on nitrogen metabolism and hormonal responses of growing beef steers. J Anim Sci 87, 681-692.

61. MacAvoy SE, Macko SA \& Arneson LS (2005) Growth versus metabolic tissue replacement in mouse tissues determined by stable carbon and nitrogen isotope analysis. Can J Zool $\mathbf{8 3}$, 631-641.

62. Martínez del Rio C \& Carleton SA (2012) How fast and how faithful: the dynamics of isotopic incorporation into animal tissues. J Mammal 93, 353-359.

63. Poupin N, Huneau JF, Mariotti F, et al. (2012) Isotopic and modeling investigation of long-term protein turnover in rat tissues. Am J Physiol Regul Integr Comp Physiol 304, R218-R231.

64. Cantalapiedra-Hijar G, Fouillet H, Huneau JF, et al. (2016) Relationship between efficiency of nitrogen utilization and isotopic nitrogen fractionation in dairy cows: contribution of digestion $v$. metabolism? Animal 10, 221-229.

65. Cantalapiedra-Hijar G, Dewhurst RJ, Cheng L, et al. (2018) Nitrogen isotopic fractionation as a biomarker for nitrogen use efficiency in ruminants: a meta-analysis. Animal 12, 1827-1837. 